\title{
The Perspectives on Philanthropic Hadiths in Panti Asuhan Muhammadiyah Lowanu Yogyakarta
}

\author{
Rohmansyah ${ }^{1, *}$ \\ ${ }^{1}$ Universitas Muhammadiyah Yogyakarta \\ *Email: rohmansyah@umy.ac.id
}

\begin{abstract}
The Perspectives on Philanthropic Hadiths in Panti Asuhan Muhammadiyah Lowanu Yogyakarta, this article discusses the perspectives on the hadiths that are used as theological foundation by Muhammadiyah in carrying out a social human movement in the form of an orphanage, which is Panti Asuhan Lowanu. The existence of the orphanage originated from social problems that occurred in the past. At that time, there were still orphans and begging neglected children who had not received attention from the community, thus encouraging this organization to take a social action by establishing the Panti Asuhan Lowanu (Lowanu orphanage) as well as providing facilities and infrastructure in it, including assistance with operational costs for all their needs, such as food, drinks and education starting from elementary school to senior high school level. For orphanage children who excel, undergraduate scholarships are provided at higher education institutions, both public and private. The hadiths about the orphanage are understood to inspire Muhammadiyah to carry out humanitarian movements that have a positive impact on the development of society, especially those who are from low economic background. They send their children to an orphanage to get religious education and general knowledge. This social action is a philanthropic movement that is framed by religious doctrine which flows from the ground up to have experienced significant development and has survived until now. This resilience is supported by the commitment of the Muhammadiyah branch administrators and the caregivers of the orphanage.
\end{abstract}

Keywords: Hadith, Philanthropy, Orphanages, Perspectives

\section{INTRODUCTION}

The social problem that is the homework of the Indonesian nation is the protection and custody of orphans and neglected children. They live in uninhabitable places, such as under bridges and others, even though on average they are 3-8 years old, the same as in the international world [1]. They strive and beg for their own food because their parents died or had left them [2]. As a result, they are not guaranteed and their needs are not fulfilled. In fact, they are just spectacles for many people, and no one cares about them instead. It is ironic to know the fact that Indonesia is a Muslim majority population but there are still many of them who do not really care about orphans and abandoned children, even tend to ignore religious orders.

There is no precise solution to this social problem other but doing philanthropic acts [3]. Philanthropy is a specific treatment done by the aghniy $\bar{a}^{\prime}$ (rich people) to those who need help [4]. Their role is very important to save orphans and abandoned children from being left behind and ignorant. Based on this phenomenon, the philanthropic discourse becomes interesting to study, especially in the handling of orphans and neglected children when associated with an organization that is the follower of the Prophet Muhammad SAW [5] [6]. The organization group is Muhammadiyah, and it proclaims itself a follower of the Prophet by proving the organization as a pioneer protector of orphans and neglected children, and also by establishing the first orphanage in the Lowanu area of Yogyakarta Special Region. The philanthropic movement is based on hadiths which instruct about caring for orphans and abandoned children.

The mentioned social problem above certainly cannot be abandoned or prevails to be an unfinished homework; thus it needs to get a full attention from all Muslims. Therefore, in this context, the writer would like to answer this problem by presenting and depicting the philanthropic movement carried out by Muhammadiyah in the social sector, by which Panti Asuhan Lowanu that becomes one of the solutions to the social problems that occurred in the past and present based on hadiths. To understand the philanthropic movement in the context of the prophetic 
hadith study, three significant research questions are formulated: First, what is the history of Panti Asuhan Lowanu? Second, what is the understanding of the hadiths which became the theological foundation by Muhammadiyah in establishing Panti Asuhan Lowanu? and Third, what are the impacts of the orphanage to the surrounding community development?

To answer the problem formulation, the writer uses Max Weber's theoretical framework. According to Max Weber in his book "The Sociology of Religions". It is stated that a person's behavior or actions are influenced by the religious or magical social motivations which are very urgent to lead to their social function, which is to control assets owned both in a family and in an organization in various fields of social life [7]. In this context, how Muhammadiyah carried out the philanthropic acts is influenced by social phenomena during the colonial period, which was then responded by the minds of its figures which were based on the Prophet's hadiths. Based on this theory, the approach used is the sociologicalhistorical approach to see the social factors that encourage Muhammadiyah to take philanthropic actions.

\section{HISTORY OF PANTI ASUHAN LOWANU}

A social movement that cares for the poor has been carried out by Ahmad Dahlan and his students since 1921 $\mathrm{AD}$ in Yogyakarta by building an orphanage institution, namely Panti Asuhan Yatim Putra dan Putri Muhammadiyah in the Lowanu area of Yogyakarta. This orphanage was the first one established by Ahmad Dahlan to accommodate and support orphans as well as those who came from poor communities and could not afford to fulfill their food and education needs. They entrust their children to the orphanage to be cared for and given education, both religious education and general knowledge including nutritional intake of food and drink so that they get their rights like children who have a father and mother (Interview, 13 February 2019).

Panti Asuhan Lowanu is the oldest orphanage in Indonesia which was established and originated by KH. Ahmad Dahlan in 1917 emphasizing the importance of supporting orphans, poor people and neglected children. The concept of KH. Ahmad Dahlan started when he studied and understood Surah al-Mā'ūn. This Surah contains threats to people who deny religion, one of which is rebuking orphans and not feeding the poor [8]. The form of the first Panti Asuhan Muhammadiyah Lowanu building is as described in the following picture:

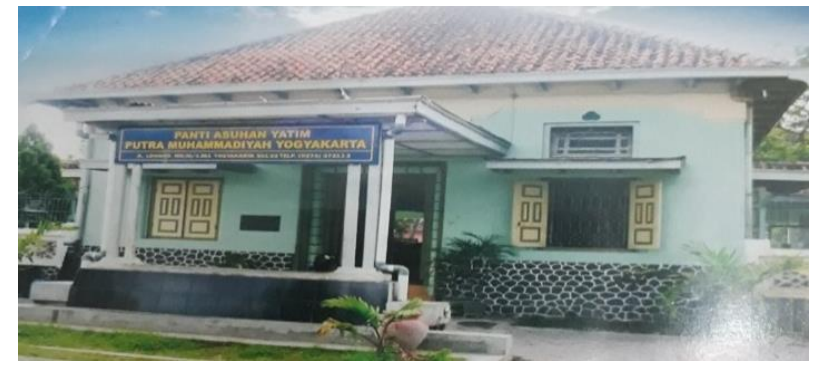

Picture 1. Panti Asuhan Muhammadiyah Lowanu

The orphanage is located on Jalan Lowanu MG III Number 1361, Brontokusuman, Mergangsan District, Yogyakarta City with a land area of about 1.1 square hectares, precisely in the Magersari area of the Ngayogyakarta Palace. Initially, KH. Ahmad Dahlan gathered the poor and orphans in the Yogyakarta city square. Then, the aghniy $\bar{a} s$, who had received religious enlightenment from him came to give their belongings. They were open to providing financial assistance because they were motivated by KH. Ahmad Dahlan's invitation through Surah al-Mā'ūn which was delivered repeatedly. KH. Ahmad Dahlan built spiritual education and high spiritual leadership so that he was able to initiate religious leadership because of Allah SWT. This has been implemented in the real life by the existence of humanitarian missions (amr ma'ruf) and liberalization (nahi munkar) which is able to generate ideal Muslim leadership characteristics, such as honesty, noble deeds, brotherhood, hardworking [9].

In 1918, a council namely Majelis Bahagian Penolong Kesengsaran Oemoem (PKO/Public Tribulation Relief) was formed. This PKO oversaw the PKU Muhamadiyah hospitals as well as functioning as a well-organized forum for orphans to support them [10]. Panti Asuhan Muhammadiyah initially consisted of foster boys and girls, then in 1928, it was divided into two: Panti Asuhan Yatim Putra Muhammadiyah and Panti Asuhan Yatim Putri Aisyiyah. In 1995, these two institutions were inaugurated by the Muhammadiyah Central Executive with the decree: Number 17 / SK-PP / IV-A / 1.c / 1995, as a manifestation of Surah Al-Mā'ūn (helping). Panti Asuhan Yatim Putra Muhammadiyah is located in Lowanu under the Branch Manager of Muhammadiyah Mergangsan Yogyakarta. Meanwhile, Panti Asuhan Yatim Putri Aisyiyah is located in Serangan area under the Regional Executive of Aisyiyah Yogyakarta. Both of these orphanages have experienced significant development over time. Therefore, it is not surprising that the two orphanages do not rely heavily on input from donors because they have business charities that can meet the needs of the orphanage. However, the orphanages still accept outside donors to support other needs. 


\section{HADITH UNDERSTANDING OF THE ESTABLISHMENT PANTI ASUHAN LOWANU}

The understanding of the hadith regarding Panti Asuhan Lowanu was intended to obtain social and historical explanations at the time of the Prophet by using the syarh al-hadīis (hadith explanation) books. As a result, clear explanation about how the hadith was conveyed by the Prophet to answer the problems of publicity that occurred at the time of the Prophet and its relationship in the present context. This explanation is refected upon the time of the establishment of Muhammadiyah which responded to social conditions based on the Prophet's hadiths.

There are Prophet's hadiths which become the basis for Muhammadiyah in carrying out the social movements, such as the hadith about protecting orphan property and hadith about loving orphans. First, the hadith about looking after orphans, as follows:

$$
\text { إتجروا فى أموال لليتامى لا تأكلها الزكاة }
$$

"Because of orphans, trade (run it) in your assets, thus it never runs out for zakat (alms)." (HR. Thabari). (Trade the assets of the orphans, don't use them for alms-giving).

This hadith was also narrated by Imam Malik in the Al-Muwatta Book. The hadith was quoted by Muhammadiyah without sanad (words resemblance) and without syakal (vowel movements). This hadith is an inspiration for Muhammadiyah to carry out a philanthropic movement, which is caring for orphans. Muhammad Soedja was a figure who was very concerned about the fate of orphans, he based his reasons on this hadith in $1925 \mathrm{AD}$ [11]. He was the youngest student of KH. Ahmad Dahlan and wrote down what his teacher uttered. At the beginning, Ahmad Dahlan did not only develop orphanages but also some shelters for helping poor people. Eventually, the shelters were not properly maintained and the orphanages were the main focus of development. The first orphanage founded by $\mathrm{KH}$. Ahmad Dahlan is Panti Asuhan Lowanu, built on the land of the Kraton Yogyakarta in 1921. Based on this initiation, Muhammad Soedja wanted to continue his teacher's struggle in carrying out caricative actions towards orphans and abandoned children. The hadith was meant to respond to the problems of poverty and ignorance during the Dutch colonial period. This problem was believed to be solved by performing some social actions or philanthropy as part of individual consciousness [12].

Ahmad Azhar Basyir said that the hadith about guaranteeing the prosperity of orphans is closely related to Surah An-Nisā 'verses 2, 6 and 10. Surah an-Nisā' verse 2 contains an order that the rights of the orphan are given to children who are entitled to receive it, and must not be exchanged and mixed with the assets of the caregivers. Surah An-Nisā 'verse 6 contains the commandment of Allah that the assets of the orphaned children shall be spent to things that are beneficial so that when they grow up, the caregivers gave the property to them. Meanwhile, Surah an-Nisā 'verse 10 contains a strong threat that people who deliberately abuse the property of the orphan for no apparent reasons, it was as if eating the embers of hell [13].

The hadith explicitly provides motivation to be able to protect and maintain the property of the orphans until adulthood so that they can find a job that is self-sufficient. The above hadith is supported by another hadith which describes the person who cares for orphans in heaven with the Prophet Muhammad SAW, it was implied from the Prophet's gestures in his index and middle fingers. The majority of the orphanage administrators and caregivers is in accordance with the following hadith:

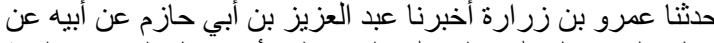

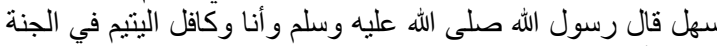

$$
\begin{aligned}
& \text { هكذا و أنثار بالسبابة و الوسطى وفرج بينهما شيئا }
\end{aligned}
$$

"Having told us Amr bin Zurārah, informing us of Abdul Azīz bin Hāzim from his father from Sahl, Rasulullah SAW said: I and the person who takes care of the orphans are in Heaven like this, and he gestures with his index and middle fingers and he stretches them between his two fingers. (Muhammadiyah, 2019: 31) \& (Al-Bukhāri, 1422: 35).

This hadith was narrated by several hadith scholars, such as Muslim, Abu Dāwud, At-Tirmiżì, Aḥmad bin Hanbal, and Mālik, as shown in the following table 1:

\begin{tabular}{|c|c|c|c|c|}
\hline No & Author & Books & Keywords & Number \\
\hline 1 & $\begin{array}{l}\text { Abi al-Husain bin Muslim } \\
\text { bin al-Hajāi. }\end{array}$ & Sahīh Muslim & 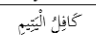 & 2983 \\
\hline 2 & $\begin{array}{l}\text { Sulaimann bin al-Ass as- } \\
\text { Siiistāni }\end{array}$ & Sunan Abi Dāwud & 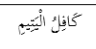 & 5152 \\
\hline 3 & $\begin{array}{l}\text { Mulamumad bin } \\
\text { Tirmiż as-Salmi }\end{array}$ & Sunan At-Tirmizì & 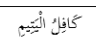 & 1918 \\
\hline 4 & Ahmad bin Hanbal & $\begin{array}{l}\text { Musnad Ahmad bin } \\
\text { Hanbal }\end{array}$ & 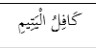 & $\begin{array}{l}8881 \& \\
22820\end{array}$ \\
\hline 5 & Mälik bin Anas & Muwatta' Mālik & 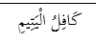 & 3491 \\
\hline
\end{tabular}

Table 1. Several Hadith

The validity of this hadith is agreed upon based on the hadith that was verified by Muslims from the path of the companion of Abu Hurairah [16]. In addition, the hadith was verified by al-Bukhāri about $A d a b$ (Islamic etiquette) from the companion of Abdillah bin Abdul Wahāb and At-Tirmiżi who verified about the kindness of the companion of Abdullah bin Imrān with title of " $\mathrm{Ka}$ fil alyatìm"(Al-Baghawi, 1983: 43).

According to Ibn Bathal, a person who hears a hadith should be fond of practicing it so that he/she can enter Heaven together with the Prophet Muhammad, the other prophets, and all of the messengers. Therefore, there is nothing more important than being with the Prophets (AlMālik, 2003: 217). This hadith is verified by another hadith which tells of a man who complained to the Prophet Muhammad that his heart was hard (not soft). Then the Prophet told him to rub the head of the orphan with his hand, and his heart would become soft, and feed 
the poor people, surely their needs will be fulfilled. The editorial of the hadith is clearly as follows:

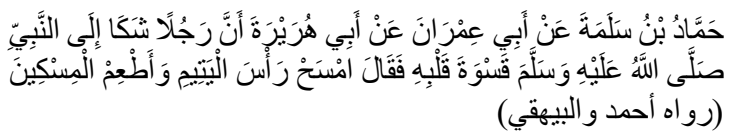

"Hammād bin Salamah from Abī Imrān from Ab̄̄ Hurairah that a man complained to the Prophet SAW about his hard heart. Then the Prophet (PBUH) said: Rub the head of the orphan (with your hand) and feed the poor." (Hanbal, 2001: 558) \& (Al-Baihaqī, 1352: 60).

The second hadith, namely the hadith about loving orphans, is also an inspiration for Muhammadiyah in caring for orphans:

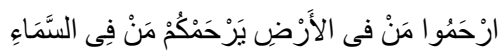

"Love people (humans) who are on earth, surely the creatures in the sky will love you)." (HR. Boechari, Aboe Daoed, Toerwoedzi and others).

The hadith above inspired Muhammadiyah to care for and love orphans as mentioned in the interpretation of Muhammadiyah's steps written by Mas Mansur in 19381940. This is a strong reason, that in 1938-1940, Muhammadiyah circles made strategic steps in loving the people on Earth. One of which was caring for orphans [21] $\&[22]$.

In full, the hadith is verified by a hadith which is similar in editorial to the hadith narrated by Abu Dāwud and Ahmad, namely:

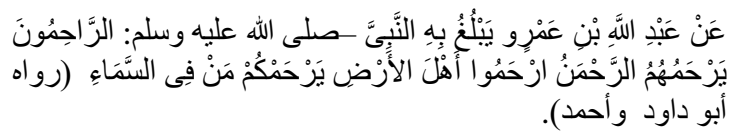

"From Abdillah bin 'Amr, he conveyed, the Prophet (PBUH) said: Those who love will undoubtedly cherished by the Most Merciful (Allah), then love the people who are on earth surely those in the sky will love you." (Abū Dāwud Sulaimān bin alAsy’aś al-Sijistāni, nd: 440) \& (Hanbal, 2001: 33).

This hadith was narrated by the hadith scholars in their book, namely Sunan Abi Dāwud, At-Tirmiż̀̄, Musnad Ahmad bin Hanbal and Aț-Tabrāni as illustrated in the following table 2:

\section{Table 2. Narrated Hadith}

\begin{tabular}{|c|c|c|c|c|}
\hline No & Author & Books & Keywords & Numbe \\
\hline 1 & Sulaimān bin al-Assy as-Sijistāni & Sunan Abi Dāwud & 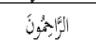 & 4943 \\
\hline 2 & $\begin{array}{l}\text { Muhammad bin Iss At-Tirmiż̄̄ } \\
\text { as-Salmi }\end{array}$ & Sunan At-Tirmiżī & 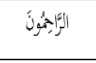 & 1924 \\
\hline 3 & Ahmad bin Hanbal & Musnad Ahmad bin Hanbal & 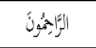 & 6494 \\
\hline
\end{tabular}

The hadith is explained by Syamsul Haq, that what is meant by ar-Rāhimūna are creatures that are on earth, both from humans and animals, they are not ordered to kill others but do something for their brothers. If they love each other, then Allah SWT will give him goodness and virtue. However, the compassion or the mercy of Allah is not only given to those who love but is given to people who adhere to the Qur'an and Sunnah, enforce Allah's laws and stay away from what is forbidden by Allah. (Ābādi, 1969: 194).

Based on this, it is important to love one another on the basis of the Qur'an and the Sunnah for fellow beings which is not just words, but with real actions to give something to people who need help, such as orphans and poor people. The tears and prayers of the helped will open the door of God's grace to those who help. This is evidenced by the Muhammadiyah organization that provides shelter for orphans and homeless children. Then they are given food, drink and schooled so that they become smart and independent and take part in Muhammadiyah as cadres and Muhammadiyah figures.

The strategy that was carried out by Muhammadiyah by establishing an orphanage was not easy. It required struggle and sacrifice of both wealth and thoughts from Muhammadiyah leaders. This is what is called jiha $\bar{d} f i$ sabilillāh (striving in the way of Allah). It is not necessarily other organizations can do it because this requires earnestness, sincerity and togetherness in upholding the philanthropic movement in Muhammadiyah. Therefore, the founder of Muhammadiyah, namely KH. Ahmad Dahlan, often advised himself and his citizens "Enliven Muhammadiyah, don't seek life in Muhammadiyah" and "Talk less, do more" (Baidhawy \& Khoirudin, 2017: 38-39). These two expressions are rooted in the next generation, namely the later figures and the administrators of the Muhammadiyah Orphanage. They believe that by helping orphans and homeless children, surely Allah will give blessings to their lives.

In addition to the above hadith, Muhammadiyah leaders also based the care of orphans and homeless children on the hadith which explains the obligation to help people who experience difficulties in life, both physically and materially, as follows:

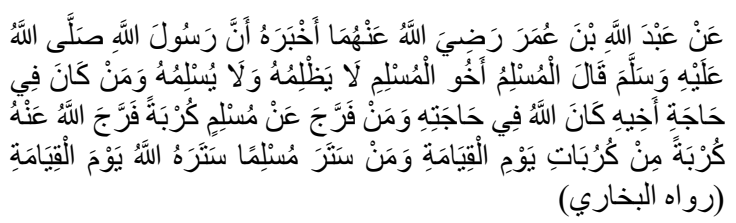

"From Abdullah bin Umar ra. Informing that Rasulullah PBUH said: A Muslim is a brother to other Muslims, so do not abuse and burdens him. Whoever helps his brother's needs, surely Allah will provide for his needs, and whoever lighten his brother's burden, undoubtedly, He will ease his burden on the Day of Judgment, and whoever covers your brother's disgrace, Allah will surely cover his disgrace on the Day of Judgment." (Narrated by al-Bukhāri)(Al-Bukhāri, 1422: 128).

The above hadith, apart from being narrated by Imam al-Bukhāri, was also narrated by Muslims, Abu Dāwud, 
At-Tirmiż̀̄, and Aḥmad bin Hanbal mentioned in their books, as mentioned in the following table 3:

Table 3. Narrated Hadith

\begin{tabular}{|c|c|c|c|c|}
\hline No & Author & Books & Keywords & Number \\
\hline 1 & $\begin{array}{l}\text { Abi al-Husaig bin Muslim } \\
\text { bin al-Hajäi }\end{array}$ & Sahīh Muslim & 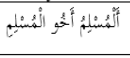 & 2580 \\
\hline 2 & $\begin{array}{l}\text { Sulaimanan bin al-Asy as- } \\
\text { Sijistāni }\end{array}$ & Sunan Abi Dāwud & 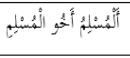 & 4895 \\
\hline 3 & $\begin{array}{l}\text { Muhammad bin isa At- } \\
\text { Tirnizizas-Salmi }\end{array}$ & Sunan At-Tirmizì̄ & 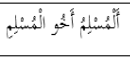 & 1426 \\
\hline 4 & Ahmad bin Hanbal & $\begin{array}{l}\text { Musnad Ahmad bin } \\
\text { Hanbal }\end{array}$ & 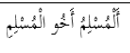 & 5646 \\
\hline
\end{tabular}

The above hadith shows the virtue of helping other Muslims by lightening up burden or hardships of their life and cover their mistakes. Covering up the mistakes of a Muslim is the advice not to spread his disgrace to others, then by doing that he will get the benefits, namely Allah SWT will cover his mistakes on the Day of Judgment by forgiving his sins. This is different from kindness. Kindness is allowed to be spread to others and even to the government (Al-Nawawi, 1929: 135). In addition, it is forbidden for a Muslim to do wrong to other Muslims even to the point of leaving him in trouble. In fact, this condition should be a field of charity to be able to help them. It is because of the attitude of helping each other, getting along well, forging unity and integrity is highly recommended in Islam (Al-Asqalān̄i, nd: 97).

The philanthropic act of establishing an orphanage, apart from being based on the aforementioned hadith, is also influenced by several Javanese social and cultural phenomena that are not in accordance with Islamic teachings. The people still carry out mystical and syncretic acts as well as animism and dynamism, thus inviting strong reactions from reformists, namely Ahmad Dahlan, who bravely clash against them and invite them to take philanthropic actions by helping poor people and orphans. [28].

\section{THE EFFECT OF PANTI ASUHAN LOWANU ON COMMUNITY DEVELOPMENT}

The existence of Panti Asuhan Lowanu towards the community's economy is not very significant because it is focused on the needs of the orphanage. So, it is not surprising that the orphanage needs a helping hand from local residents. The orphanage is not a field to earn sustenance and seek profit, but as a field of charity for every human being who wants to do good deeds. However, excess assistance such as rice was given back to the poor around the orphanage as a way to strengthen ties with the community. This has a positive impact on the surrounding community. They feel helped by the existence of the orphanage. This orphanage was established to help poor people who cannot support their children for daily life and school fees. They believe that the orphanage can provide the best for their children. Actions to care for these orphans, actually have long been carried out in London in 1869. There is a special organization called the London Charity Organization Society (COS) [29]. In general, these actions help the poor, as was done by Muhammadiyah, although not in a material form.

In general, the Panti Asuhan Lowanu has a positive influence on the people both able and poor who are divided into several classes, namely the upper-class, middle-class and lower-class people. First, the upper-class people are those who are well off and have permanent jobs. They are rich and generous people who are called to help the orphanage in terms of money and basic food. It is undeniable that the role of benefactors is very helpful for the orphanage to continue to progress, survive and develop until now. This is where the power of infaq (voluntary charity) and alms can give blessings to life both to those who give and those who receive assistance. Most of them are motivated by the benefits of life and motivated by the lectures of Muhammadiyah leaders who lead the recitation every Saturday morning alternately based on the Qur'an and the hadith of the Prophet. The hadith of the Prophet motivated the rich to give as stated in the hadith of the Prophet "that the best possible house that is favored by Allah is a house in which there are glorified orphans." Apart from the hadith, they are also motivated by the hadiths mentioned above. Therefore, the upper-level people, namely the rich get the benefits of living with the existence of an orphanage in a worldly and ukhrawi (heavenly) manner.

Second, middle-class people are those who have permanent jobs, but are not able to fulfill their daily needs maximally because the income earned is smaller than the expenses. Even so, some of them want to help the orphanage with the salary that they only have. They did not even expect a dime in return. They sincerely sacrifice their energy and thoughts for the advancement of the orphanage so that it continues to develop, as did the caregivers and administrators of the orphanage. Some people still give part of their property in the hope that their sustenance will increase their blessings and get assurance from Allah, namely Heaven. This is based on the researcher's experience in observing each orphanage, especially the Panti Asuhan Lowanu. However, there is a negative stigma against the orphanages because orphans get shelter, facilities and educational opportunities as experienced by 300 orphanages in Cambodia with around 12,000 children [30]. Therefore, the condition that the local residents feel jealous of the orphanage is inevitable.

Third, lower-class people are those who do not have permanent jobs and do not have enough income. This affects the situation of their children. They can only send their children to elementary school level or cannot even pay for their children to go to school. Therefore, some of them choose a path that is considered good by sending their children to an orphanage as a solution to save their children from hunger and ignorance. This shows that the existence of the orphanage is very beneficial for the people of Yogyakarta in particular and the wider community in general. It is because the orphanage does not only provide food nutrition but also provides religious knowledge and general knowledge. Religious education is deliberately taught in the orphanage with teachers from 
Muhammadiyah religious leaders, while general education is taught in elementary schools, junior and senior high school according to their respective levels of education. Indirectly, Panti Asuhan Muhammadiyah Lowanu helps the government in solving cases of poverty and homeless children and educates Indonesian children so that they can continue their education to a higher level and they become successful people, even though it seems independent in alleviating poverty [31]. So that in the end the children who were successful became regular donors of the orphanage. This training model is a characteristic of Muhammadiyah which may be different from other orphanages, which only providing food and bed assistance without paying attention to the educational aspect. This kind of action was not only carried out in Yogyakarta but also in Sumatra and other regions [32].

\section{CONCLUSION}

The hadiths about philanthropy are understood to be the theological basis of the birth of Panti Asuhan Muhammadiyah in Lowanu which is influenced by social problems that occurred in the past, namely the condition of orphans and homeless children who tend not to get attention from the community. This encourages Muhammadiyah to carry out social change by providing assistance to the community in order to obtain their rights as befits middle and upper levels of society. These hadiths become religious doctrine for this organization in caring for and saving them, namely orphans and neglected children from ignorance, poverty and underdevelopment, so that they get proper education both religious and general education and get health insurance.

\section{REFERENCES}

[1] et. A. Robert B. Mccall, "A Socioemotional Intervention in A Latin American Orphanage," Infant Ment. Health J., vol. 31, no. 5, pp. 521542, 2010.

[2] S. Katyal, "A study of resilience in orphan and non-orphan children," Int. J. Multidiscip. Res. Dev., vol. 2, no. 7, pp. 323-327, 2015.

[3] H. Latief, Politik Filantropi Islam di Indonesia: Negara, Pasar dan Masyarakat Sipil. Yogyakarta: Ombak, 2013.

[4] I. Piliyanti, "Transformasi Tradisi Filantropi Islam : Studi Model Pendayagunaan Zakat, Infaq ," Economica, no. November, pp. 1-14, 2010.

[5] R. Rohmansyah, Kuliah Kemuhammadiyahan. Yogyakarta: LP3M Universitas Muhammadiyah Yogyakarta, 2018.

[6] S. Jurdi, 1 Abad Muhammadiyah: Gagasan Pembaharuan Sosial Keagamaan. Jakarta: Kompas, 2010.

[7] B. S. Turner, Relasi Agama \& Teori Sosial Kontemporer. Yogyakarta: IRCiSoD, 2012.

[8] M. Arifin, Muhammadiyah Potret yang Berubah. Yogyakarta: Suara Muhammadiyah, 2016.

[9] Tobroni, The Spiritual Leaderhip: Pengefektifan Organisasi Noble Industry Melalui Prinsip- prinsip Spiritual Etis. Malang: UMM Press, 2010.

[10] R. Rohmansyah, M. Zuhri, and A. Danarto, "The Contextualization of Philanthropic Hadiths at PKU Muhammadiyah Hospital, Yogyakarta," Religia, vol. 22, no. 2, pp. 136-159, 2019.

[11] PP Muhammadiyah, "Pendirian Rumah Miskin," Suara Muhammadiyah, Suara Muhammadiyah, Yogyakarta, 1925.

[12] A. Fauzia, Faith and the State: A History of Islamic Philanthropy in Indonesia. Leiden: Brill, 2013.

[13] A. A. Basyir, Syarah Hadis Tentang Iman, ilmu dan amal. Yogyakarta: Persatuan, 1985.

[14] P. P. Muhammadiyah, Buku Pedoman Pengasuhan Anak Muhammadiyah. Yogyakarta: Majelis Pelayanan Sosial, 2019.

[15] M. bin I. bin I. bin al-M. al-J. Al-Bukhāri, Șah̄ịh al-Bukhāri, Vol. 8. Beirūt: Dār al-Ṭūq al-Najah, 1422.

[16] A. M. bin al-H. al-Q. al-N. Al-Husain, Șaḥịh Muslim, Vol. 1. Riyāẹ: Bait al-Afkār alDawliyyah, 1998.

[17] A.-Husain bin M. Al-Baghawi, Syarh al-Sunnah. Beirūt: al-Maktabah al-Islāmi, 1983.

[18] A. bin K. bin A. Al-Mālik, Syarḥ Sahịh alBukhāri li Ibni Batțāl, Vol. 3. Riyāḍ: Maktabah al-Rusyd, 2003.

[19] A. bin Hanbal, Musnad al-Imām Ahmad bin Hanbal, Vol. 42. Beirūt: al-Muassasah alRisālah, 2001

[20] A. bin al-Husain bin A. Al-Baihaq̄̄, Sunan alKubrā lil al-Baihaqī. Hindia: Dāirat al-Ma'ārif al-'Arabiyah, 1352.

[21] M. Mansur, Tafsir Langkah Muhammadiyah. Yogyakarta: Suara Muhammadiyah, 2013.

[22] P. P. Muhammadiyah, Manhaj Gerakan Muhammadiyah, Ideologi, Khittah, dan Langkah. Yogyakarta: Suara Muhammadiyah, 2010.

[23] Abū Dāwud Sulaimān bin al-Asy'aṡ al-Sijistāni, Sunan Abī Dāwud, Vol. 2. Riyāẹ: Bait al-Afkār al-Dawliyyah.

[24] A. al-Ṭīb M. S. al-Ḥaq al-A. Ābādi, 'Aun alMa'būd Syarh Sunan Abi Dāwud. Madīnah alMunawwarah: Al-Maktabah al-Salafiyah, 1969.

[25] Z. Baidhawy and A. Khoirudin, Etika Muhammadiyah \& Spirit Peradaban. Yogyakarta: Suara Muhammadiyah, 2017.

[26] A. Z. Y. bin S. bin M. Al-Nawawi, Syarh alNawawi 'ala Muslim, Vol. 16. Kairo: AlMaṭba'ah al-Mișriyyah bi al-Azhar, 1929.

[27] A. bin A. bin Hajar Al-Asqalānī, Fath al-Bārī bi Syarh Ṣah̄ịh al-Bukhārī, Vol. 10. Beirūt: Dār alMa'rifah.

[28] H.-J. Kim, Reformist Muslims in a Yogyakarta Village: The Islamic Transformation of Contemporary Socio-Religious Life. Australia: ANU E Press, 2007. 
[29] R. Humphreys, Poor Relief and Charity 1869 1945: The London Charity Organization Society. London: Palgrave, 2001.

[30] K. Carpenter, "Using Orphanage Spaces to Combat Envy and Stigma," Child. Youth Environ., vol. 24, no. 1, pp. 124-137, 2014.

[31] M. Fuad, "Civil Society in Indonesia: The Potential and Limits of Muhammadiyah," Sojourn J. Soc. Issues Southeas Asia, vol. 17, no. 2, p. 133, 2002.

[32] H. M. Federspiel, "The Muhammadijah: A Study of an Orthodox Islamic Movement in Indonesia," Cornell Univ. Press. Southeast Asia Progr. Publ. Cornell Univ., pp. 57-79, 1970. 